\title{
Temporal Deixis in Balinese Language
}

\author{
I. Nyoman Kardana ${ }^{1 *}$, Made Sri Satyawati ${ }^{2}$ \\ ${ }^{1}$ Faculty of Letters, Warmadewa University, Denpasar-Bali, Indonesia \\ ${ }^{2}$ Faculty of Humanities, Udayana University, Denpasar-Bali, Indonesia
}

Corresponding Author: I. Nyoman Kardana, E-mail: ikardana@yahoo.com

\section{ARTICLE INFO}

Article history

Received: September 08, 2018

Accepted: November 20, 2018

Published: February 28, 2019

Volume: 10 Issue: 1

Advance access: January 2019

Conflicts of interest: None

Funding: None

\begin{abstract}
This study analyzed the forms of temporal deixis found in Balinese, one of the biggest local languages in Indonesia. Data was collected from oral communication by Balinese speakers who live in Denpasar, the capital city of the island of Bali. Data was obtained through observation and elicitation method completed with recording and note taking technique. The collected data was analyzed by inductive approach so that the clear and detail description about temporal deixis could be reached. The result of analysis shows that the forms of Balinese temporal deixis can be divided into the forms referring to the past, present, and future tense. The forms are also distinguished between definite and indefinite temporal deixis. Two kinds of temporal markers are also found in Balinese, they are di marker for past and buin/bin marker for future. The form mani and $i b i$ does not obligatorily need the markers but the other temporal forms really need the markers to make a complete meaning and reference.
\end{abstract}

Key words:

Balinese,

Temporal Deixis,

Marker,

Definite,

Indefinite,

Oral Communication

\section{INTRODUCTION}

Balinese language is one of the biggest local languages existing in Indonesia. It is the only local language spoken by Balinese people living in the island of Bali. It is also used by Balinese people who live in other part of Indonesia when they communicate among them. As a part of the greatest archipelago of Indonesia, the island of Bali is very popular in the world as one of tourist destinations in Indonesia. In addition to the daily activity, Balinese language is commonly used for formal meeting and activities regarding religion of Hindu, Balinese traditional and custom affairs. Recently, a bit problem raises dealing with the existence of Balinese. The young people, especially who live in cities they prefer using Indonesian language (national language) and English or other foreign languages to Balinese. This happens because of at least two reasons, (1) they have less understanding and ability in using Balinese, (2) they often interact and communicate with different ethnics and tribes in Indonesian and even they often use English to speak with foreigners staying in Bali. However, the Balinese people living in country sides (young or adult) they mostly use Balinese in various situations and activities.
Balinese has a lot of phenomena related to its structure and function in social and cultural uses. The phenomenon needs observing in order to give clear and deep explanation to the young people and to make them easy to study the language as well. If they understand the language they may use it well in every situation. To prepare material for learning, observation in the field of structure becomes very important to do. Related to this rationale, describing the forms and functions of any language elements would be very important. It will be useful if it is connected with their uses in context. For instance, the study about temporal deixiss in Balinese. In Balinese there are various kinds of temporal deixis. The temporal deixis or sometimes called temporal adverbials are realized by word(s) or phrase, and clause as well (Artawa, et.al, 2018). Furthermore, Artawa, et.al (2018) analyzed only the temporal adverbials in Balinese filled in by a clause. They classified the category of temporal adverbials semantic function realized by a clause into temporal location, frequency, and miscellaneous. To make is concern, this study only focuses on Balinese temporal deixis filled by word(s) or phrase. The problems discussed in this study are: (1) What are the forms of the temporal deixiss found in Balinese? and (2) What tense and situation 
is referred by the forms?. Based on the problems, this study aims at analyzing the forms of temporal deixiss found in Balinese language including their uses in various situation for their daily communication. Thus, the speaker (commonly the young Balinese people) can understand the reference or the deixis of the time in an utterances or sentences are not only based on the meaning of the forms of the temporal deixis but based on the situation and the contextual use of the forms as well. This phenomenon may be considered as one of the uniqueness the language has because the uniqueness may deal with the structure of the Balinese and its relationship with the context of situation and other fields of life (Kardana, 2014:169).

\section{LITERATURE REVIEW}

Deixis often called reference is mostly related to the context of a sentence. Saeed (1997: 180) says that much of reference or deixis involves reliance on context, together with some calculation on the part of the speaker and hearer. Temporal deixis is in a close analysis with temporal adverbials. Artawa,et.al (2018:76) say that temporal adverbials as the realization of the temporal deixis can be shown by words, phrase or a clause. When we try to get the point of time that the temporal adverbial refer we have been discussing temporal deixis. In Hexagonal French there are two future temporal forms under investigation, they are inflected or morphological future and periphrastic future (Roberts,2012:97). According to both prescriptive and pedagogical grammars, the principal linguistic factor conditioning variant selection in the future tense reference system is the temporal distance between speech time and the future eventuality (Hawkins and Towell 2001, Grevisse and Goosse 2008 in Roberts, 2012:97). Then, temporal distance is subdivided according to whether the action was set to occur within the hour, the day, the week, or beyond a year (Roberts, 2012:99).

\section{METHODOLOGY}

In this study, descriptive method is chosen to apply in order to make a systematic and accurate description on the data, characteristic, and phenomenon related with the observed data (Djajasudarma,1993:8). Data of this study is classified into written and spoken data. Written data was taken from a famous novel written in Balinese and the spoken one was obtained from Balinese informants living in Bali when they were using Balinese in their communication. Data was collected through observation and interview method. Some techniques, like recording and note taking techniques were applied to complete the methods in collecting complete data to achieve satisfaction result (Sudaryanto, 1993:133). Then the collected data was analyzed based on the inductive approach. This inductive approach is very important to analyze the characteristics of the natural data of Balinese that is not all possibly analyzed by the available theories (Kardana, 2017). The data was analyzed particularly based on the aims of this research. It means data was classified into the kinds of forms of the temporal deixis and their uses in Balinese text.
There are some criteria applied to determine informants of this study, they are: (1) adult native speaker of Balinese, (2) not too much influenced by other languages, (3) be smart and have competence to speak Balinese well, (4) have enough time, (5) be ready to be good informant, and (6) have normal/good articulation tools (Samarin, 1988:65--70; Bawa, 1992:7). The author as the native speaker of Balinese has great chance to create data and the created data will be re-checked to the informants to obtain the appropriate data (Kardana, 2010:126).

\section{RESULTS AND DISCUSSION}

There are many different forms of temporal deixis found in Balinese and some of them can show their reference based on the context in a sentence. The forms and the reference of the temporal deixis in Balinese can be seen in the following discussion.

\section{Past Temporal Deixis.}

There are some temporal forms used to refer past time. The forms can be distinguished into form showing definite and indefinite past time. The detail explanation for the phenomenon can be seen in the following explanation.

\section{Definite Past Temporal Deixis: mare, tuni, (di) ibi, (di) puan, (di) telun}

The forms above are commonly used to refer definite past time deixis and they have particular definite period of time. The temporal time forms that refer to the past (except mare and tuni) is sometimes completed with the presence of $d i$ before the forms. They can be seen in the following examples:

(1) Ia mare teka uling peken PR3 just come from market 'She has just come from market'

(2) Tuni bapanne ada jumah A few hours ago father-POSS there is home 'A few hours ago his father was at home'

(3) Ibi ia maan mulih, kewala sing ngorahang apa. Yesterday PR3 get home, but not speak-SUF what 'Yesterday he came home, but he did not say anything'

(4) Di puan tiang masih ke kantor maragatang gaene. Two days ago PR1 also to office finish work-DEF 'Two days ago I also came to office to finish the work'

(5) Asananga di telun ia teka uling badung Approximately three days ago PR3 come from Badung

'It seems that He came from Badung three days ago'

The form of temporal deixis at the sentences above refer to past definite time because they have past particular period of time. They may not have ambiguous reference and they do not depend on the context. The form of mare at (1) refers to e few minutes before the utterance, tuni refers to a few hours before the utterance, ibi at (1) refers to a day before the utterance, di puan at (2) refers to two days before the utterance, and di telun at (3) refers to three days before the 
utterance. As mentioned above that the presence of di before the form of puan at (4) and telun at (5) is optional. Beside definite reference, the temporal forms for past indefinite deixiss are found as well in the collected data. They can be seen in the following discussion.

\section{Indefinite Past Temporal Deixis: di telunan, (di) ibi puan, di puanan, (di)ibi-puanan}

From the data we can see that the addition of suffix - an makes definite temporal deixis become indefinite deixis, for instance: di telun $\rightarrow$ di telunan, di puan $\rightarrow$ di puanan, and dibi- puan $\rightarrow d i-$ bi-puanan. It can be seen in the following discussion.

(1) Ia maan teka mai di teluanan ajak memenne. PR3 get come here three days ago-SUF with mother-POSS

'She came here with her mother about a few days ago/about three days ago'

(2) Di puanan memenne maan mablanja mai meli uyah. two days ago-SUF mother-POSS get shop here buy salt

'A few days ago/about two days ago her mother came here to buy salt'

(3) Dibi-puanan ia biasa mai, sakewali jani tusing taen ngenah.

Yesterday-two days ago-SUF PR3 usually come here, however now never look

'He used to come here, but he does not any more now'

The form of di telunan, di puanan and dibi-puanan at the constructions above are not referring to the definite past deixis as mentioned by the base of the forms such as telun 'three days before the utterance', puan 'two days before the utterance but they all refer to indefinite past deixis meaning 'a few days before the utterance'. The presence of $d i$ before telunan and puanan is obligatory but it will be optional for ibi puan and ibi puanan.

Other several examples of the indefinite forms are as below. The temporal forms are used when a speaker wants to tell about the time when the activities happen in the past and the time is not bound by certain period.

(6) A: Pidan kurananne mulih De?

When wife/husband-POSS come home De

'When did your husband come home?'

B: Sube ada di telunan.

Already there is thre days ago-SUF

'About few days ago'

(7) Yen ibi-puan anak ia sing rewel cara kene If yesterday-two days ago person PR3 not fussy like this

'He was never fussy before and not like what he is doing now'

(8) Ibi-puanan ia rajin mai melali, jani sing taen, sibuk jenenge.

Yesterday-two days ago-SUF PR3 diligent come here travel, now not ever, busy may be 'He often came here for friendship before'

\section{Present Temporal Deixis}

Balinese has also particular forms for the present time deixis. The forms are distinguished between temporal forms for present definite temporal deixis and indefinite temporal deixis. They can be seen in the following discussion.

\section{Definite Present Temporal Deixis: jani, jani san}

The number of the forms referring to definite present temporal deixis is limited only for jani and jani san. The ussage of the both forms can be seen in the following examples.

(1) Meme bapanne jani sedek di carike. Mother father-POSS now CONT in rice field 'His parents are now in the rice field'

(2) Ia ngorahin apang jani san iraga meragatang gaenne.

PR3 tell so that now right we finish work-DEF

'He told us to finish the work right now'

Temporal form jani and jani san above have definite temporal deixis for the particular time in the present when the utterance is being spoken. The form of jani at (1) means the time of the utterance and the additional element of san to the jani $\rightarrow$ jani san become the form refer to the second of the utterance 'right now'.

\section{Indefinite Present Temporal Deixis: jani, ajanian}

The form jani is not only used for definite deixis, but it can be also used to refer the indefinite present temporal deixis. The reference can be determined according to the context.

(1) Jani panakne sube magae di kantoran Now child-POSS already work at office 'Now his son has been working at an office'

(2) Jani otonan panake paling cenik Now Balinese birthday child-POSS most small Today is his son Balinese birthday'

(3) Jani sube masan duren Now already season duren 'Now is the season of duren'

(4) Pemerintahane jani luungan teken ane sube lewat Governance-POSS now better from which already past

His governance is much better than the past period governance'

(5) Ia ajanian tusing taen gedeg ajak tiang PR3 as long as not ever angry with PR1

'Up to now he has never been angry with me'

Temporal form jani in the examples above look to have different reference to those in the example of definite temporal deixis. The form jani at (1) refers to the recent days of the utterance, jani at (2) refers to the day of the utterance, jani at (3) refers to the fruit season when the utterance is spoken, and jani at (4) refers to the period of the current president's authority of the utterance. However, the form ajanian at (5) refers to indefinite time up to the time of the utterance. 


\section{Future Temporal Deixis.}

Roberts (2012) said that in spoken Hexagonal French there are two variants for future temporal deixis, they are inflected future (e.g. je partirai 'I will leave') and periphrastic future (e.g. je vais partir 'I am going to leave'). However, this study only focuses on the word(s) or phrase forms in Balinese. Based on the collected data Balinese has various forms for future temporal deixis. The forms can be distinguished between forms referring to definite temporal deixis and those referring to indefinite temporal deixis. All the future forms can be completed with $d i$ before them. The presence of $d i$ may be optional for some forms and can be obligatory for other ones. The analysis of the future temporal deixis can be seen in the following discussion.

\section{Definite Future Temporal Deixis: (buin/bin) nyanan, (buin/bin) mani, buin/bin puan, buin/bin telun, etc.}

The forms of nyanan and mani is sometimes completed with a marker of buin/bin 'again' so that the forms can buin/bin mani, buin/bin nyanan. However, the form puan and telun must be completed with the marker of buin/bin 'again'. This is because the form nyanan and mani have already future meaning but the word puan and telun have past meaning and they can be reffering to future if they are completed with the buin/bin marker. Thus, if the form of puan and telun are without bin marker or with $d i$ marker, they will refer to the past deixis.

The examples the definite future temporal deixis are as discussed below.

(1) Nyanan mai nah jani konden peragat later come here okay now not yet finish It is not finished yet, Please come here later'

(2) Jani dogen pragatang. Nyanan tiang mulih ke Klungkung.

Now only finish. Later PR1 go home to Klungkung 'Let's finish it now. I will go home to Klungkung later'

(3) Bli Made mejanji lakar mai bin mani

Brother made promise will come here MRK tomorrow

'Brother Made promised to come here tomorrow'

(4) Bin puan lakar ada Joged di Bale banjar. Mabalih mai!

MRK two days will there is jogged at hall society. watch okay

The day after tomorrow there will be Joged dance. Please come and watch!'

The temporal form of nyanan at (1) and (2) above refers to the time after the utterance is spoken (particularly in the afternoon time if the utterance is spoken in the morning or day time). The form bin mani at (3) refers to the definite temporal time for future. The form bin mani refers to the day after the day of the utterance. The bin marker in bin mani can be omitted because the form mani has already referred to future. The form bin puan at (4) is also used for future time and the form refers to two days after the day of the utterance.
However, in the form of bin puan, the bin marker can not be omitted since the form puan does not definitely refer to future but it may be laso used for past deixis. It may refer to future if it is completed with buin/bin. If it is bare or with $d i$ it will belong to past definite deixis. For example, (di) puan refers to the two days before the day of the utterance and bin puan refers to the two days after the day of the utterance.

\section{Indefinite Future Temporal Deixis: (bin) nyanan, (bin) nayananan, (bin) manian, (bin) mani-puan, (bin) mani- mani, bin puanan.}

From the collected data the form of indefinite future temporal deixis in Balinese can be divided into simple form, reduplicated form, suffixed-form, compounding, and reduplicated-suffixed form. Suffix used to mark the indefinite future deixis is suffix - an. The simple form for indefinite future deixis is nyanan, meanwhile the reduplicated form is mani-mani; the suffixed forms are nyananan, manian, puanan, compounding form is mani-puan, and the reduplicated-suffixed form is mani-manian. From the data below it seems that suffix - an attached to the definite temporal deixis has changed the form into indefinite temporal form, i.e mani (definite deixis) $\rightarrow$ manian (indefinite deixis), puan (definite deixis) $\rightarrow$ puanan (indefinite deixis), nyanan (definite/indefinite deixis) $\rightarrow$ nyananan (indefinite deixis). All the indefinite form above can be completed with future marker of buin/ bin. However, the presence of buin/bin marker is not obligation to the all forms except the form of puanan because all the forms contain the form of nyanan or mani which already has particular future deixis. In another way, the presence of buin/bin marker is obligatory to the form of puan since the form more refers to past than future. Look at the following examples.

(1) Manian tiang singgah merika.

Later PR1 stop over there.

'I will come and visit you to your house later'

(2) Bin mani-puan sing dadi keto buin. Benehang awake magae.

Again tomorrow tow days no become so again

'You may not make mistake again later. Please do the best'

(3) Bin mani-mani yen lakar luas ke Klungkung orahang nah.

Again tomorrow-RED if will go to klungkung tell okay

'Next time if you will go to Klungkung, Please let me know'

(4) Ajak mai nyanan kurenanne nah apang taen tawang.

Take here this afternoon wife/husband-POSS okay so that ever know

'Please take your wife here so that I have a chance to know her'

(5) Nyananan ngae ento nyak, jani melali malu.

This afternoon-SUF make that okay, we go for a walk now

Let's do it later, we go for a walk now' 
All constructions above contain indefinite future temporal deixis forms. The form of manian 'later/next time' at (1) results from definite base form mani 'tomorrow' with suffix - an and the form manian becomes indefinite deixis because of the suffix -an, compound form mani-puan 'later/next time' at (2) derives from two definite forms mani 'tomorrow' and puan 'two days before/after' and the compound refers to indefinite deixis, the indefinite reduplicated form mani-ma$n i$ at (3) derives from the simple definite mani 'tomorrow'. The presence of buin/bin marker before mani-puan and ma$n i$-mani at (2) and (3) is optional. If the marker is omitted, the forms are still acceptable in those constructions. It is because the forms have the base mani which has particular future deixis. Then, the form nyanan at (4) refers to indefinite deixis and it is different from the form nyanan for definite deixis as in the example (1) and (2) of the previous analysis of the definite deixis. It means that the form nyanan can be used for both definite and indefinite future temporal deixis depend on the context of the situation. The element of language (in this point is nyanan) that is so contextually bound is called deictic (Saeed, 1997:173), The indefinite form nyananan derives from base nyanan and suffix -an. The suffix has changed the definite form nyanan into indefinite form nyananan.

\section{CONCLUSION}

Based on the analysis it could be concluded that Balinese has several forms of temporal deixis. The form can be distinguished between those which refer to past, present, and future tense. The forms used for the three different time can be divided into definite temporal deixis and indefinite temporal deixis. However, there are the same forms that can be used for both definite and indefinite and they can be determined by the context of the situation. There are some temporal forms that need temporal markers to mark them to the past or future deixis. The two kinds of temporal markers found in Balinese are di for past and buin/bin for future. The forms that do not obligatorily need the markers are $i b i$ 'yesterday' and mani 'tomorrow' because the forms already have particular definite deixis. The forms of temporal deixiss found in Balinese language are: definite past temporal deixis: mare, tuni, (di) ibi, (di) puan, (di) telun; indefinite past temporal deixis: di telunan, (di) ibi puan, di puanan, (di) ibi-puanan; definite present temporal deixis: jani, jani san; indefinite present temporal deixis: jani, ajanian; definite future temporal deixis: (buin/bin) nyanan, (buin/bin) mani, buin/bin puan, buin/bin telun, etc; indefinite future temporal deixis: (bin) nyanan, (bin) nayananan, (bin) manian, (bin) mani-puan, (bin) mani-mani, bin puanan.
ABBREVIATION
CONT = continuous tense
$\mathrm{DEF}=$ definite
MRK = marker
POSS = possessive
PR1 = first pronoun
PR3 = third pronoun
RED $=$ reduplicated
SUF $\quad=$ suffix

\section{REFERENCES}

Artawa, K., et al. (2018). "Temporal Adverbial Clause Markings In Balinese” International Journal of Linguistics, 10(2), 173-86.

Bawa, I W. (1992). Kalimat Aktif Bahasa Bali. Denpasar: Universitas Udayana. p.7.

Djajasudarma, T. Fatimah. (1993). Metode Linguistik: Ancangan Metode Penelitian dan Kajian. Bandung: Eresco. p. 8 .

Kardana, I N., et al. (2014). "Morphosyntax of Balinese Reciprocal Constructions" International Journal of Linguistics, 6(4),168-180.

Kardana, I Nyoman. 2017. "The Predicate Category and Characteristics of Arguments in Balinese Sentences" International Journal of Linguistics. Vol.9, No.5, p.126-141.

Roberts, N. S. (2012). "Future Temporal Reference in Hexagonal French" University of Pennsylvania Working Papers in Linguistics. 18, Article 12. Penn Libraries University of Pennsilvania.

Saeed, J. I. (1997). Semantics. Oxford: Blackwell Publishers Inc.

Samarin, W.J. (1988). Ilmu Bahasa Lapangan (Diterjemahkan oleh J.S Badudu). Yogyakarta: Kanisius. p.65-70.

Sudaryanto. (1993). Metode dan Teknik Analisis Bahasa. Yogyakarta: Duta wacana University Press. p.133. 